Barriers to brand building in UK universities ? 


\section{Barriers to brand building in UK universities?}

Chris Chapleo

Portsmouth University Business School

Richmond Building

Portland Street

Portsmouth PO1 3DE

E mail chris.chapleo@port.ac.uk

Telephone : 02392844793 


\begin{abstract}
Branding in universities has become an increasingly topical issue with practitioners, with some institutions committing substantial financial resources to branding activities. It has, however, received only limited academic investigation, and as the particular characteristics of the sector present challenges for those seeking to build brands, it seems to be timely and appropriate to investigate potential barriers to branding.

This exploratory study investigates the opinions of the 'brand guardians' of UK universities - Vice Chancellors, Principals and Rectors - on the barriers to successfully building brands and draws conclusions on their views of the key challenges facing successful branding activity in the sector. Implications for practitioners are also explored.
\end{abstract}


Introduction

This paper concerns the barriers to brand building in UK universities. Branding seems to be topical among UK education marketing practitioners where "the education press has been full of stories about branding exercises in higher education" (Stamp 2004, p7).

Aaker (1996) asserts that brands are 'pivotal resources for generating and sustaining competitive advantage'. If we assume this to be true, then Louro and Cunha's (2001) argument that brand management is a central organisational competence that needs to be understood and developed has significant implications in an age of increasing competition among UK universities.

However, UK education branding seems to have received only limited academic investigation, and as an organisation's approach to branding determines its understanding of brands and the process of brand strategy ( Louro and Cunha 2001), the specifics of UK higher education (HE) seem worthy of further investigation.

The objectives of this research were;

- To explore current knowledge and opinion (both academic and practitioner) of issues affecting branding in universities.

- To explore perceptions of potential and actual barriers to branding amongst leaders of UK universities.

- To further the debate and inform practice on the issues surrounding university branding.

Overall, the qualitative methodology of the research and its exploratory nature aim to further the debate on barriers to branding in UK higher education.

The term Chief Executives is used in this paper to denote leaders of UK universities. Their specific titles include Vice Chancellor, Rector, Principal and Chief Executive but the latter was considered an appropriate term to encompass the modern nature of the role of head of a university.

\section{Literature review}

Interpretation of brands

It may be argued that 'brand' is a somewhat subjective term. As Kapferer (2001, p3) argues "the reality of the modern brand makes us realise that there are different types of brand....in reality, no one is talking about precisely the same thing".

In conducting this research it was, however, necessary to provide interviewees with a consistent definition of what was meant by the term 'brand', particularly as the sample in this research were not necessarily formally trained in marketing and branding.

Upon examining existing academic definitions of 'brand', a' two factor' approach forms the broad basis for many definitions with writers such as De Chernatony and Mc William (1990) and Caldwell and Freire (2004) suggesting brand definitions based on 'emotional' and 'rational' factors. This approach is summarised by Pringle and Thompson (1999), arguing that there are two main constituents to a brand's authority: its rational or performance benefits and its emotional or image ones. Louro and Cunha (2001) embrace these and add 'strategic' and 'relational' dimensions in arguing that brands are multidimensional.

De Chernatony and Riley (1998, p427), in investigating definitions, ultimately suggest that a brand is "a multidimensional construct whereby mangers augment products or services with values and this facilitates the process by which consumers confidently recognise and appreciate these values". This statement was used as the basis of the definition put to interviewees. 


\section{The concept of branding in higher education}

Brand management in the specific context of higher education is an area that has been on the agenda of practitioners for some time, but has seemingly received only limited academic attention.

Universities have parallels with non profit brands such as museums and galleries in that they have increasingly come under pressure to act as businesses (Kotler and Kotler 1998), and Stamp (2004) offers a number of factors which have driven the UK HE branding agenda including tuition fees, competitive differentiation, league tables, organisations attaining university status and the mis-match between brand perceptions and delivery. The increased need for international recruitment has also caused UK universities to consider international brand image, and this presents dilemmas, particularly for the Asian markets targeted in recent times, in terms of standardised or adapted brand strategies (Gray, Fam and Llanes 2003).

Johnson (2001), however, argues that UK universities have a long way to go in terms of understanding and incorporating the branding concept. It seems that necessity is forcing UK universities to adopt the concepts and practices of branding, but that the current perceived wisdom may not necessarily be suited to the specific needs of the university sector.

\section{Barriers to brand building in universities}

Clearly any organisation faces certain challenges in building and maintaining strong brands, but the pertinent question is whether particular issues face universities in their branding activity.

Bodoh and Mighall (2003, p23) argue "brands will present some real challenges in a sector that has been slow to embrace the basic principles of branding". Johnston (2001) sums up the consensus from practice journals at that time when he argues that the higher education system certainly has a long way to go in terms of understanding and incorporating the branding concept. In academic journals higher education marketing is discussed by papers such as Brookes (2003), but there is little examination of branding as a specific area within this. The US, however, appears to be ahead of the UK in the acceptance and implementation of branding as a concept in the sector. Work by Sevier (2004) and Kotler (1995) support this, suggesting that branding in US HE has become accepted practice. This may be because the US has gone through the clash of cultures between the traditional academic values and market focused values ten years earlier (Sanders 1999).

Looking at the charity sector, which arguably demonstrates similarities with the education sector ( not least its non-profit status), Hankinson (2001, p231) argues that little scholarly activity has been devoted to use of brand because of "arguably greater complexity", and "difficulties in committing internal stakeholders to branding concepts", and this view is supported by Schultz and Barnes (1999). It seems reasonable to argue, therefore, that the specific barriers to building brands in the UK university sector are worthy of further primary investigation.

\section{A number of areas of possible investigation become apparent through the existing literature: Organisational complexity}

Hankinson (2001) states that a central requirement of successful branding is consistency in what the brand represents, but argues that organisational complexity and control undermine this. The author suggests that an appropriate organisational structure is necessary to support brand consistency and this could have implications for brands in universities, with their rather complex structures. This organisational complexity may be exacerbated by diversity in brand management paradigms that significantly magnify the field's complexity ( Louro and Cunha 2001). Brookes (2003, p140) suggests that commercially focused activities such as branding are inherently difficult for universities where "one has to take into account the needs of relevant linking departments that do not have solely commercial objectives".

Caldwell and Coshall (2002), investigating museums and galleries, concluded that if the brand is focused towards a relatively small number of constructs shared by a large percentage of visitors, they will address the needs of large 
audiences. Parallels for the HE sector may suggest, therefore, that any model needs to identify these constructs for the particular university in question.

It is suggested that one of the primary functions of brand management is to co-ordinate, monitor and adjust interactions between an organisation and its stakeholders (Schultz and Barnes 1999) such that there is consistency between an organisation's brand vision and stakeholders' brand beliefs. Any model, therefore, must be able to encompass and embrace the complex stakeholder environment of universities.

\section{Differentiation}

Several models such as LePla and Parker's 'Integrated Brand Model' (2002), De Chernatony and Mc William's 'Brand Box Model'(1990), and Kapferer's 'Brand Identity Prism' (1992) note that identification of a clear 'brand principle' is vital, but a clear 'principle' may be difficult to encapsulate for university brands, with their 'complexity' (Hankinson 2001) in terms of stakeholders, internal organisation and inherent diversity of provision of products.

A number of writers, whilst not considering higher education organisations in particular, have alluded to some of the challenges faced by the HE sector. De Chernatony and Segal-Horn (2001) consider what differentiates successful brands in service industries from those in product marketing and argue that service companies often follow a 'monolithic' branding strategy, which may lead consumers to mentally group the entire organisation's portfolio together, expecting uniformity from their service offerings. Arguably, the nature and structure of universities does not easily lend itself to consistency of service delivery and customer service.

Dibb and Simkin (1993) dispute the commonly held belief that marketing in general and branding in particular are less well developed in services than in products. They suggest that the intangibility and inseparability of services makes branding even more important but accept that branding is not well developed across all service sectors, citing education as an example of such. These authors discuss Harvard Business School as an example of a strong brand in education, however, arguing that it is strong because customers know exactly what it stands for and has a clear position in consumer's minds. They go on to link this concept of positioning to branding, suggesting that Harvard has "a strong brand image" in the sense that it "is clearly positioned in consumer's minds" (and they offer other universities as examples in this area, arguing that "Oxbridge, the 'Red-Bricks' and the former polytechnics are generally viewed as quite different to each other" and therefore uniquely positioned. This, they suggest, indicates that "the marketers in these organisations have practised marketing effectively for decades" (Dibb and Simkin 1993, p 30). They do concede, however, that it is often the case that positioning has "just happened or has emerged in a somewhat ad hoc manner over time", which may in fact be the case for many universities in the UK and is therefore at odds with the previous statement.

Internal Stakeholders and the Internal Brand

It has been suggested that marketing, by its very nature, 'invades' most areas of the organisation , and that there is therefore a likelihood that marketing people will run headlong into the strongly held views of other staff and departments (Low and Fullerton 1994). Cultural resistance to the ethos and practice of branding may therefore be an issue for UK universities; indeed Brookes (2003) argues that underpinning marketing philosophies are 'theoretically uncomfortable' for many academics. Hankinson (2001), working with the charity sector, identifies 'difficulties in committing internal stakeholders to branding concepts'.

Keller (2003) argues that customer 'experience' is crucial, whilst Hankinson (2004) suggests the need for an organisational 'behavioural' element' in successful branding. This may, therefore, offer some important ideas for the branding of universities, where employees and their attitudes and actions shape perceptions of the brand. 


\section{'Desirability' of a branding ethos}

Sargeant's (2005) suggestion that branding in non profit sectors can create a spirit of unhealthy competition, prompting others to undertake similar expenditure of dubious benefit, may have relevance to the higher education sector. This argument may be countered to some extent by the view that, in a world where political and market forces make competition inevitable, brands can be both a strategic asset and a source of sustainable competitive advantage (Caldwell and Coshall 2002). Blumenthal and Bergstrom (2003) argue that the brand should be inextricably linked to corporate and social responsibility of an organisation and therefore offers something 'of substance' to help stakeholders differentiate between organisations. 'Doyle (1989) believes simply that branding 'makes the consumer's choice process more effective' and this alone could be argued to offer a rationale for branding's applicability to HE. De Chernatony and Riley (2000) suggest that ideally consumers choose to have a relationship with a brand if they trust it to deliver specific promises. The 'marketing nirvana' of a brand as a clear shorthand for an organisation that consumers trust to deliver on their needs could reasonably be argued to be desirable for all organisations, whether non-profit or otherwise.

In conclusion, it would seem that the primary investigation of possible barriers to brand building in UK universities serves the purpose of helping clarify not only underpinning conceptual assumptions but practical implementation in a sector that may face difficulties in adopting wholly commercial approaches.

\section{Methodology}

The main focus of the research was to 'seek a deeper understanding of factors' (Chisnall 2001) pertaining to branding UK universities. It was decided to interview Chief Executives of UK universities as they are suggested to be the group with whom brand ownership lies (Free 1999), which Miles and Huberman (1994, p28) refer to as "politically important cases": "salient informants who may need to be included because they connect with politically sensitive issues anticipated in the analysis". Fifteen interviews were carried out in 2003 among Chief Executives representing 3 different types of university, based on incorporation dates: Newer (1992 and post1992) universities, 'Red-Brick' (1950s-1960s) universities and Older universities (incorporated before 1950). The average duration of each interview was 26 minutes. These respondents were selected through what can be termed a 'judgement sample of people used to gather insights into the phenomenon' (De Chernatony and Riley 1998).

A key epistemological issue concerned an 'interpretivist' approach that sought 'to understand the social world through an examination of the interpretation of that world by its participants' (Bryman and Bell 2003). However, it is accepted that in qualitative research of this nature "the boundary is never quite as solid as a rationalist might hope" (Miles and Huberman 1994, p27). The sample size, whilst appropriate for an exploratory qualitative study, can at best be argued to offer indicative results or 'generalisations' that put flesh on the bones of general constructs (Miles and Huberman 1994) and it is accepted that results are hopefully representative but not necessarily conclusive.

Semi-structured interviews were considered appropriate, as a picture of respondent's true feelings on an issue was desired (Chisnall 1992). This technique aims to gain the perspectives of informants so that the research topics could be explored (Daymon and Holloway 2004) and is similar to that adopted by other studies on brands, such as that by Hankinson (2004). An interview guide was used to steer the discussion, but respondents were also allowed to expand upon ideas and concepts as they wished.

The particular questions explored in the context of the interviews linked back to the objectives of exploring current knowledge and opinion on issues affecting branding in universities, in particular exploring leaders of UK universities perceptions of potential and actual barriers to branding in their institutions. 
Questions explored:

- Understanding of branding in the HE context

- Responsibility for the brand of an institution

- Brandings' role in differentiating the institution

- Particular challenges in building and managing a brand in the HE sector

The interviews were transcribed and subjected to content analysis to look for commonalities in responses or trends through coding (Miles and Huberman 1994). It is important to emphasise that the anonymity required by respondents makes direct attributing of quotes difficult. However, a number of pertinent quotes were attributed by category of university in an attempt to at least partly address this issue.

\section{Findings and discussion}

\section{Understanding of branding in the HE context}

A number of respondents drew a distinction between the 'reputation' of their institution and the 'brand'. Brand was felt to be distinct from reputation in that it has more commercial connotations. It was suggested that brand is a "commercial term that has crept, not inappropriately, into the vernacular of HE" ('Red-Brick' Chief Executive) although one respondent talked of "brand still being an uncomfortable term to use with many academics" ( Old University Chief Executive) It was apparent that most Chief Executives did clearly perceive a broad meaning of the term brand to include such elements as 'values' 'quality' and 'personality' as well as the narrower visual elements of logo, strap line, font styles etc. This was not universally the case, however, with two Chief Executives only citing the visual elements of what constitutes a brand, one initially describing it as a "visual image or logo" (New University Chief Executive).

It was also notable that several respondents talked of 'brand' being 'created' or 'manufactured', in contrast to the reputation of an institution which may be seen as "coming about through evolution" ( New University Chief Executive).

\section{Who is responsible for managing the brand?}

All but one Chief Executive suggested that they had a key role in managing the brand of their institution. However, there was variance in suggesting whether brand management filtered down from the top or was built from the bottom up. For example, one New university Chief Executive suggested that "presenting it and delivering it is the concern of the University Management Team" whereas another talked clearly of the "development of common vision ....decided by all staff" ('Red-Brick' Chief Executive) Another 'Red-Brick' Chief Executive summarised his view of how the process of branding should work as "we need to understand our own self image....once we define that internally then we can hope that everybody throughout the university helps to promulgate that brand", but conceded that "we quite candidly haven't done that as well as we should". The variance in defining the Chief Executive's role in the branding process was argued to be a factor that differentiated universities from commercial organisations, where the "role of the leader was thought to be more clearly defined in terms of brand custodian" (New university Chief Executive).

A group cited as important in managing the university brand was the marketing department, but a distinction can be drawn here in terms of their role in the branding process. Approximately half of the Chief Executives suggested that their role was to oversee marketing professionals in managing the brand. New university Chief Executives generally suggested that marketing should 'guide in brand construction', whereas the 'Red-Brick' and Older university Chief Executives alluded more to 'implementation' and one talked of "leaving it to marketing not being enough". Whether there is significance in this split is debatable, but clearly the role and relationship of marketing in brand management has yet to be fully defined.

In summary, most interviews seemed to suggest that the Chief Executives perceived a need to gain internal acceptance for the brand and thereafter to decide upon presentation and communication in conjunction with senior colleagues (and generally, but not always, marketing). This arguably demonstrates a fundamental difference from the majority of commercial organisations. 


\section{Does the brand differentiate the institution?}

It was also interesting that almost all the Chief Executives considered that their institution was differentiated by their brand to some extent, with the exception of one Old university Chief Executive who felt that his institution was "differentiated in subject areas but not overall by brand". However, it appeared that many of the points suggested as differentiators were in fact very similar to other institutions, with newer universities offering some 'brand values' which suggest real differentiation, whilst three 'Red Bricks' felt that they were only partially differentiated. It was in this middle group that the greatest proportion of Chief Executives expressed concern that their institution would have difficulty with genuine overall differentiation, with the general subtext being that their offering was intrinsically similar to other universities of comparable age and quality.

Older universities in particular were felt to be 'differentiated', but how many of these are genuine points of differentiation and how many could apply to a number of institutions is open to debate; it was felt by several interviewees that 'reputation' is also seen as a key differentiator among older universities.

\section{Particular challenges for brand management in the university sector}

A degree of commonality in responses on this issue was apparent and the main suggested factors can be reasonably summarised as:

\section{1. 'Institutional resistance to change'.}

The key phrases here were the 'institutional culture' and 'cultural legacy', which were seen as challenging in relation to commercial activities such as branding. This may simply be indicative of the issues facing Chief Executives when trying to build a clear brand for a complex organisation which has not historically had a commercial focus. The issues here are perhaps summarised by a 'Red-Brick' Chief Executive who felt that 'the sector overall demonstrated a slowness to change' and an Old University Chief Executive who stated that "universities are not very good at selling themselves because they have never had to".

One 'Red-Brick' Chief Executive made an interesting comment in suggesting that internal building of a brand was hindered by the feeling that some "staff work at the university, but not for it". Several Chief Executives suggested that the language of branding was not 'always comfortable' or even 'culturally acceptable'.

\section{2. 'Difficult to construct a real overall convincing brand that captures ethos and diversity'.}

This point follows closely from the previous one in that it alludes to the difficulty of branding an institution such as a university. The consensus was that universities are by nature complex and diverse institutions and the task of neatly encapsulating this in a set of simple brand values was difficult to say the least - a challenge shared by other non-profit organisations such as charities and museums (Hankinson 2006).

Several Chief Executives suggested that, whilst they had a brand, it did not accurately reflect current reality. One Old University Chief Executive summed up this point, arguing that his university "has a strong brand that comes out of the reputation but, paradoxically, one that relates very poorly to what we do now".

\section{3. 'Nature of brand model; lack of clear model to construct a brand'.}

It was suggested that there is no evidence of a clear model for constructing a brand in institutions such as universities. One 'Red-Brick' Chief Executive asked "do we build one strong overall brand which encompasses everything we do and all our services or do we have a series of strong sub brands which have a higher profile than the overall institutional brand?"

\section{4. 'Sub branding - schools/ faculties who want a distinct reputation'.}

Several Chief Executives cited this as a hindrance to building a brand, although this was tempered by others who identified it as an issue but not necessarily negative. Business Schools were cited as an example of where it may actually be beneficial. Two interviewees were aware of this issue but felt that it did not affect their institutions, as the overall institutional brand was strong enough. This appears to be another area where there is no simple model or answer to suggest whether it is a positive or a negative and what the best practice should be?

\section{Conclusions}

Overall the concept of branding seemed to be embraced and supported among Chief Executives of 
UK universities, probably reflecting external pressures. However, even allowing for the exploratory nature of the research, findings do suggests that there are a number of issues apparent in UK universities that make building and maintaining fully developed brands in the commercial sense challenging:

1. Whilst leaders of UK universities are supportive of the concept of branding their institution, the results indicate a degree of variance in terms of how these leaders perceive their role. This clearly overlaps with the area of 'internal brand management', where defining roles and relationships of leaders, senior management, marketing practitioners and 'everybody in the institution' in brand management is also a difficult issue.

2. Lack of internal acceptance and support for the branding concept was also identified as an issue, and is probably not helped by lack of clear role definition as discussed in the previous point. Clear definition and leadership combined with internal marketing may be important issues, but the evidence of cultural resistance may point to deeper issues needing more fundamental solutions.

3. Faculties or schools building sub brands in their own right - this is not necessarily thought to be a problem by all, but it is something that may need active management consideration, rather than the seeming 'organic evolution' of sub brands suggested by this research.

4. Finally, difficulty in identification of a clear 'brand principle' or point of differentiation has been suggested to be a major problem for most of the sample. A common focus is generally intrinsic to a branding principle (Le Pla and Parker 2002) but this very 'common focus' can be difficult to attain in universities that ultimately provide many similar 'products'.

To end on a positive note, whilst it is possible to list many barriers to brand building the research did suggest that Chief Executives embrace the concept of brand management, see their role in this as key, and are keen to address the difficulties that are perceived. This move towards 'branding culture awareness' is suggested to be the first step in the brand building process (Urde 1999).

In conclusion, the research suggests a need for further evolution of the discipline of brand management and subsequent modelling of branding concepts to universities .A number of identified issues make this a highly challenging task, but growing external commercial pressures seem likely to catalyse this need for further investigation of the branding concept in universities.

\section{Implications for practitioners}

It is apparent that there are challenges facing UK universities in terms of brand management, but there are a number of positive steps that university leaders and marketing practitioners may consider:

1. One positive factor is Chief Executives' apparent acceptance of the importance of the issue of brand management. This readiness to embrace the concepts is likely to lead to a proactive rather than reactive approach to the challenge.

2. There is an opportunity, therefore, to more clearly understand current perceptions of the institution (through research?) and thereafter clearly articulate a desired brand positioning, rather than arrive at one by default.

3. The issue of real differentiation is particularly challenging. Many UK universities have strong historical and cultural legacies, which, once understood, may offer a clear foundation for future brand design and communication, although if genuine differentiation through brand is ultimately considered desirable and necessary, this may entail some bold and often contentious branding decisions.

4. Internal acceptance; this appears to be critical for a real and sustainable brand and consideration should be given to how to win acceptance of staff at all levels. A clear starting point is to call for the importance of the concept of branding itself. It has been suggested that over time funding imperatives will lead to cultural shifts which more easily facilitate internal acceptance. Internal Marketing programmes may also have an important future role to play here.

5. Loyalty is a starting point for internal acceptance. The attitude of working 'at the university' and not 'for the university' appears to be widespread and addressing the cultural issues which have fostered this attitude, whilst not easy, may be necessary in the long term.

6. Organisational structure is a key issue. Brookes (2003, p141) suggests separating business administration 
(including marketing and branding) from academic "to allow both specialists the freedom to develop their own work". This, however, could present its own internal communication challenges.

\section{Further Research}

This was an exploratory study and as such has provided indicative results which raise further questions.

Particular issues that may be in need of further exploration include:

1. Whilst the study explored a key group of opinion formers opinions, the research would benefit from further empirical study among other stakeholder groups such as education marketing and branding practitioners, and key 'customer' groups.

Further to this, wider work could attempt to move towards addressing some of the identified issues:

2. Are any UK university brands perceived as 'successful', and can best practice examples be taken from these?

3. Can a theoretical model for university brand analysis and management be developed?

4. Can current internal marketing theory and practice be applied to the higher education sector? 
Aaker D A. 1996. Building strong brands. The Free Press: New York

Bodoh J, Mighall R. 2003. Study here because you're worth it. The Times Higher Education Supplement. March 7. 23

Bergstrom A J, Blumenthal D. 2003. Brand councils that care: Towards the convergence of branding and corporate social responsibility. Journal of Brand Management 10: 327-341

Brookes M. 2003. Higher Education: Marketing in a quasi-commercial service industry. International Journal of Nonprofit and Voluntary Sector Marketing. 8: 2: 134-142

Bryman A, Bell E. 2003. Business Research Methods. Oxford University Press

Caldwell N, Coshall J. 2002. Measuring brand associations for museums and galleries using repertory grid analysis. Management Decision. 40: 4: 383-392

Caldwell N, Freire J R. 2004. The differences between branding a country, a region and a city: Applying the Brand Box Model. Journal of Brand Management 12: 50-61.

Chisnall P M. 1992. Marketing Research. McGraw Hill: Maidenhead, UK.

Chisnall P. 2001. Marketing Research. Mc Graw Hill: Maidenhead, UK.

Daymon C, Holloway I. 2004. Qualitative Research Methods in Public Relations and Marketing Communications. Routledge: London

De Chernatony L, McWilliam G. 1990.Appreciating brands as assets through a two -dimensional model. Journal of Marketing Management 9: 173-188.

De Chernatony L, Riley F D’ O. 1998. Defining A "Brand": Beyond The Literature With Experts' Interpretations. Journal of Marketing Management 14: 417-443.

De Chernatony L, Riley F D’ O. 2000. The Service Brand as Relationship Builder. British Journal of Managemet. 11 : 137-150

De Chernatony L, Segal-Horn S. 2001. The Criteria for Successful Service Brands. European Journal of Marketing. 37: 7/8: 1095-1118

Dibb S, Simkin L. 1993. The Strength of Branding and Positioning in Services. International Journal of Service Industry Management. 4:1: 25-35.

Doyle P .1989. Building Successful Brands: The Strategic Options. Journal of Consumer Marketing. Spring 1990: 7:2: 5-20

Free C. 1999.The internal brand. Journal of Brand Management 6: 231-236.

Gray B J, Fam K, Llane V. 2003. Branding universities in Asian markets. Journal of Product and Brand Management. $12: 2: 108-120$.

Hankinson G. 2001.Location branding: A study of the branding practices of 12 English cities. Journal of Brand Management 9: 127-142.

Hankinson P. 2004. The Internal Brand in leading UK Charities. Journal of Brand Management 13: 84-93. Hankinson P. 2006. Personal Correspondence. March 2006.

Johnston A. 2001.Branding - the key to student recruitment (or maybe not).Education Marketing. March.28-29

Kapferer J N. 1992. Strategic Brand Management. Kogan Page: London

Kapferer J N. 2001. (Re) Inventing The Brand. Kogan Page: London

Keller K L. 2003. Strategic Brand Management: Building, Measuring and Managing Brand Equity. Prentice Hall: New Jersey

Kotler P, Fox K .1995. Strategic Marketing for Educational Institutions, Prentice Hall, New Jersey.

Kotler P, Armstrong G, Saunders J,Wong V. 1999. Principles of Marketing; Second European Edition.

Prentice Hall Europe, London

Kotler N, Kotler P. 1998. Museum Strategy and Marketing: designing missions, building audiences, generating revenues and resources. Jossey- Bass: San Francisco,USA.

Le Pla F J, Parker L M. 2002. Intergrated Branding. Kogan Page: UK

Louro M J, Cunha P V. 2001.Brand Management Paradigms. Journal of Marketing Management 17: 849-75.

Low G S, Fullerton RA. Brands, Brand Management , and the Brand Manager System: A Critical -Historical Evaluation. Journal of Marketing Research Vol XXXI ( May 1994) 173-190

Miles M B, Huberman A M. 1994. Qualitative Data Analysis: an expanded sourcebook. Sage: USA

Pringle H, Thompson M. 1999. brand spirit: how cause related marketing builds brands. Wiley: Chichester, UK 
Proctor T. 2000. Essentials of Marketing Research. Pearson Education: Harlow UK

Sanders C. 1999. Universities go for a spin. Times Higher Education Supplement. Analysis, 10 December 1999, p.8

Sargeant A. 2005. Marketing Management for Nonprofit Organizations $2^{\text {nd }}$ edition. Oxford Press, Oxford Saunders M, Lewis P, Thornhill A. 1997. Research Methods for Business Studies. Pitman: London

Schultz D, Barnes B E. 1999. Strategic Brand Communications Campaigns. NTC Business Books: Chicago Sevier R. 2004. Personal correspondence. May 2004

Stamp R .2004. The new challenge of branding buy-in. Education News. Winter 2004, p7, Euro RSCG Riley. Urde M. 1999.Brand Orientation: A mindset for building brands into strategic resources. Journal of Marketing Management 15: 117-133 